\title{
Entry Points on Forming Cross-culture Awareness and Moral Quality in College English Textbooks
}

\author{
Beili Liu \\ Beijing Information Technology College \\ Beijing, China
}

\begin{abstract}
With the problem of "weakening or even ignoring the cross-culture teaching and moral education infiltration" in college English classes, this paper aims at studying the entry points in the college English textbooks on putting cross-culture knowledge into the college English teaching to cultivate students' cross-culture awareness and moral quality. First, English teachers should set examples themselves. They must have positive moral qualities and rich knowledge on cross-culture. Second, teachers should design the teaching activities by hearts. By taking a variety of English activities into learning cross-culture knowledge, and through cross-culture teaching and moral education infiltration in the English textbooks both on the similar parts and the different parts, students not only improve their cross-culture awareness and moral quality on the basis of learning English knowledge.
\end{abstract}

Keywords-college English textbooks; cross-culture awareness; moral education

\section{INTRODUCTION}

Language is the carrier of culture. The famous American linguist Sapir, as early as 1921 pointed out "Language does not exist independently from the culture. Language not only expresses but contains facts and symbolic culture." (Kramsch, 1998) Therefore, language teaching cannot be separated from culture teaching. Cultural teaching and language teaching should have equally important status. Culture teaching on the one hand, provides the real language teaching context to improve language ability and communication skills, on the other hand makes learners understand the target language culture and thus make reflection of their mother tongue culture, which improves their intercultural awareness.

The definition of "moral education" in Han Dian is "The main teaching content and teaching objective is to develop students' moral consciousness, moral judgment and moral practice." Moral education is the foundation of all education. College public English teaching syllabus also explicitly points out college students should be cultivated the moral accomplishment and humane spirit during the course of learning.

College students have more than 10 years' experience of learning English, however, most students' purpose to learn English is to cope with the examination. Teachers and students focus much more on improving the students' English language knowledge and skills, which weakens or even ignores the cross-culture teaching and moral education infiltration. Cross-cultural teaching and moral education infiltration lag in the long-term of English teaching.

English-culture learning and the formation of crossculture awareness not only can improve college students English comprehensive application ability, but also can improve the students' humanistic knowledge, enhance their humanistic quality, and expand their horizons. The students can deal with the problems in the future life and work in an easier manner. In addition, the cultivation of college students' cross-culture awareness also has a positive role on students' moral education practice. The cross-culture teaching in college English classroom is one of the effective ways to undertake to the students' moral education infiltration.

\section{COURSE PREPARATION}

Through the cross-culture teaching to make moral education infiltration in college English classroom, teachers need to prepare for the cross-cultural teaching and course design fully at the early stage.

\section{A. Improvement of the Teachers' Moral Education Quality}

Currently most college English teachers are young, and they are growing up under the exam-oriented education environment and lack of cross-culture knowledge themselves Therefore, teachers should improve their cross-culture awareness before teaching. In the first place, teachers should master the cross-culture knowledge. Only the teachers themselves have a certain cross-cultural knowledge level, can they be likely to undertake it to the students in a right way, and give students the correct learning. In the second place, teachers need to improve their own moral accomplishment. In this way, the teaching process is more has persuasive.

\section{B. Curriculum Design}

In order to better blend the cross-culture content into the college English teaching; teachers need to do a lot of preparation in the curriculum design job.

First of all, teachers should try to find the appropriate cross-culture knowledge that can be introduced into the English classroom teaching. Thus, teachers must understand the content of the course completely, and find out the crossculture points which are close to the teaching content, and 
guide the students to compare Chinese culture with western culture. Culture cannot be judged as good or bad. Different cultures have different characteristics, people should respect every culture. Teachers can encourage the students to make comparisons between Chinese culture and western culture, and discuss whether Chinese can borrow some western culture or not.

In addition, reasonable teaching activities' design should be made. Teachers should create a relaxed and happy learning atmosphere as much as possible, which can fully mobilize students' enthusiasm of learning. Students can feel the charm of moral spirit during the course of English learning, and in the meantime, put the moral spirit as the behavior's guidance and correct the bad qualities in them.

Ultimately, teachers should pay attention to the students' feedbacks, understand their feelings and the status of their English learning. According to the students' feedbacks, adjustment should be made to the teaching contents and teaching activities.

\section{CROSS-CUlture AND Moral QuAlity TEACHING PRACTICE}

After teachers are fully prepared for the course, they can put the cross-culture teaching and moral education into practice in the flowing ways.

\section{A. Development of Cross-culture Knowledge Related Activities}

In order to put the cross-culture content into English teaching, teachers should put the heads together, and develop lively and interesting teaching activities for the students. For example, teachers can organize the students to study western culture in the English edition, and hold cross-culture knowledge competition. Moreover, teachers can guide the students to compare Chinese culture with western culture. Furthermore, team activities can be taken to discuss the western culture which is worth the taking for reference. Teachers can also guide the students to write essays with topics of western culture. Rich and colorful activities can arouse the enthusiasm of the students' learning in crossculture knowledge, and subtly undertake the moral education to students.

\section{B. Cross-culture Teaching and Moral Education}

Infiltration in the English Textbooks on the Similar Parts

Teachers can take the appropriate topics as the entry points, choose the English texts which contain the similar parts in both Chinese culture and English culture, and take the opportunities to conduct moral education to the students. On the basis of English-text teaching, Chinese and western cultures can be put into the classes. Students can taste the wonders of both Chinese culture and western culture.

Take the textbook the 21 st Century University English (Zhai Xiangjun, 2008) which is published by Fudan University Press as an example. The text entitled Thanks, Mom, for All You Have Done is a letter to the author's mother before the Mothers' day's coming. The author recalled the stories with his mother in the process of his growth-his mother's care and instructions to him. The author's mother set herself an example to him. The author expressed his gratitude to his mother. Text His Life's Work tells the story of a father, after the death of his wife, who refused the relatives' help to avoid the separation from his children and brought up seven children ranging in age from 2 to 16 on his own. This text reveals the father's love, meticulous care among family members and the children's gratitude to their father.

While teaching the two English texts, teachers can introduce the content of "filial piety" in Chinese culture, and encourage the students to search on the internet and share some famous "filial piety" stories in the traditional Chinese culture with others. Teachers make the students understand "filial piety" is the most important part in an individual's existence in society, and realize the old saying "hundred good, filial first" in the Chinese traditional culture. In this way, the students can taste that both Chinese and western cultures are similar in the part of parents-children's love.

Furthermore, by learning the two texts, teachers may guide the students to make self-reflection. The students can tell the love between their parents and themselves, share their own parent-love stories with other students, and understand the uneasy life of their parents, and show love and gratitude to their own parents. In this way, the moral quality objective is achieved.

\section{Cross-culture Teaching and Moral Education Infiltration in the English Textbooks on the Different Parts}

Teachers can guide the students to make comparisons between Chinese culture and western culture involved in the textbooks. For example, "westerners' attitudes on treating work and life, their concepts of educating children, their views on punctuality, their opinions on love, their spirits on the exploration of natural science and so on." (Wei Chunxia, 2011) Teachers may take the opportunities and let the students discuss the places where we can learn from the different cultures, and undertake moral education infiltration to the students.

For example, also in the text Thanks, Mom, for All You Have Done, teachers can tell the students that the degree of dependency between parents and children is different in Chinese and western cultures. Chinese children are closer and more dependent with their parents. It is common for the grown-ups to live together with their parents. But westerners are relatively independent. It is uncommon to share the same house with their parents when they are adults.

Besides, teachers can make the students discuss the different ways of expressing "thanks" between Chinese culture and western culture, which can show that Chinese people are implicit and shy while westerners are explicit and open. Westerners often say "Thank you." to their close relatives and friends, but Chinese people are not. Chinese people think it regards their relatives as outsiders if saying "Thanks." to them. When the students associate with the westerners, they should pay attention to the culture 
difference and behave appropriately or they may tell the international friends this difference and do not make foreigners feel Chinese people are not polite or offensive. On the other hand, the students should understand both the Chinese way and the western way to expressing thanks are correct. The importance is to have a grateful heart. This example is an entry point that can arouse the students' crossculture awareness and form their moral qualities on the basis of English textbooks learning.

In the process of English teaching, by putting into the learning of intercultural knowledge, and undertake to students' moral education, not only can make the students learn English knowledge wholly, but also make the students form the cross-culture awareness, so as to constantly improve their moral quality, put the knowledge education, cultural education and moral quality education together to achieve the perfect combination.

\section{CONCLUSION}

By the appropriate entry points of putting the crossculture knowledge into the practice of college public English classroom teaching the students can learn English knowledge and at the same time improve their cross-culture awareness and their moral qualities. Teachers should be good at choosing the entry points in the college English textbooks, which are mainly classified into two categories-crossculture teaching and moral education infiltration in the English textbooks on the similar and different parts. In addition, the comparison and compromise of Chinese culture and western culture play positive roles on the proper way of the students' using English in the real world. And in this way, there are more interesting English classes on the basis of English textbooks. Thus, arouse the students' enthusiasm on English learning. Finally, the process of culture comparison and moral reflection improves the students' abilities of critical thinking which are also essential.

\section{REFERENCES}

[1] Kramsch, Claire. Language and Culture [M]. Oxford: Oxford University Press, 1998: 23.

[2] Zhai Junxiang. The 21st Century University English [M]. Shanghai: Fudan University Press, 2008: 76-77, 92-93.

[3] Wei Chunxia. Culture infiltration and Moral Cultivation in University English Teaching [J]. Journal of Chifeng College, 2011(12):221. 